\title{
11ß-Hydroxysteroid dehydrogenase enzymes in the testis and male reproductive tract of the boar (Sus scrofa domestica) indicate local roles for glucocorticoids in male reproductive physiology
}

\author{
Victoria Sharp, Lisa M Thurston, Robert C Fowkes and Anthony E Michael ${ }^{1}$ \\ Endocrine Signalling Group, Department of Veterinary Basic Sciences, Royal Veterinary College, Royal College Street, \\ London NW1 OTU, United Kingdom and ${ }^{1}$ Division of Clinical Developmental Sciences, Academic Section of \\ Obstetrics and Gynaecology, Centre for Developmental and Endocrine Signalling, St George's University of London, \\ London SW17 ORE, United Kingdom
}

Corresponding author should be addressed to V Sharp; Email: vsharp@rvc.ac.uk

\begin{abstract}
$11 \beta$-Hydroxysteroid dehydrogenase (11 $\mathrm{HSD})$ enzymes modulate the target cell actions of corticosteroids by catalysing metabolism of the physiological glucocorticoid (GC), cortisol, to inert cortisone. Recent studies have implicated GCs in boar sperm apoptosis. Hence, the objective of this study was to characterise 11ßHSD enzyme expression and activities in the boar testis and reproductive tract. Although $11 \beta \mathrm{HSD} 1$ and $11 \beta \mathrm{HSD} 2 \mathrm{mRNA}$ transcripts and proteins were co-expressed in all tissues, cortisol-cortisone interconversion was undetectable in the corpus and cauda epididymides, vas deferens, vesicular and prostate glands, irrespective of nucleotide cofactors. In contrast, homogenates of boar testis, caput epididymidis and bulbourethral gland all displayed pronounced $11 \beta \mathrm{HSD}$ activities in the presence of $\mathrm{NADPH}_{\mathrm{NADP}}{ }^{+}$and $\mathrm{NAD}^{+}$, and the penile urethra exhibited $\mathrm{NAD}^{+}$-dependent $11 \beta$-dehydrogenase activity. In kinetic studies, homogenates of boar testis, caput epididymidis and bulbourethral gland oxidised cortisol with $K_{\mathrm{m}}$ values of 237-443 and 154-226 nmol/l in the presence of NADP ${ }^{+}$and NAD ${ }^{+}$ respectively. Maximal rates of $\mathrm{NADP}^{+}$-dependent cortisol oxidation were 7.4- to 28.5-fold greater than the $V_{\text {max }}$ for $\mathrm{NADPH}$ dependent reduction of cortisone, but were comparable with the rates of $\mathrm{NAD}^{+}$-dependent cortisol metabolism. The relatively low $K_{\mathrm{m}}$ estimates for $\mathrm{NADP}^{+}$-dependent cortisol oxidation suggest that either the affinity of $11 \beta \mathrm{HSD} 1$ has been increased or the cortisol inactivation is catalysed by a novel NADP ${ }^{+}$-dependent $11 \beta \mathrm{HSD}$ enzyme in these tissues. We conclude that in the boar testis, caput epididymidis and bulbourethral gland, NADP ${ }^{+}$- and $\mathrm{NAD}^{+}$-dependent $11 \beta \mathrm{HSD}$ enzymes catalyse net inactivation of cortisol, consistent with a physiological role in limiting any local actions of GCs within these reproductive tissues.

Reproduction (2007) 134 473-482
\end{abstract}

\section{Introduction}

Physiological glucocorticoids (GCs) exert a number of deleterious effects on Leydig cells, including inhibition of testosterone biosynthesis, suppression of luteinising hormone receptor expression and induction of Leydig cell apoptosis (Bambino \& Hsueh 1981, Monder et al. 1994b, Gao et al. 1997). It has also been speculated that GCs might regulate ion and fluid transport across the epithelia of the epididymidis and vas deferens, and affect erectile function in the rat (Waddell et al. 2003). Although GCs have recently been reported to induce apoptosis in boar spermatogonia (Claus et al. 2005), the physiological relevance of GCs in the boar testis and reproductive tract remains poorly understood at present.
In potential target tissues, the physiological GCs, cortisol and corticosterone, can be reversibly converted to their inactive 11-ketosteroid metabolites (cortisone and 11-dehydrocorticosterone respectively) by $11 \beta$-hydroxysteroid dehydrogenase (11ßHSD) enzymes (Bush et al. 1968). Although $11 \beta \mathrm{HSD} 1$ is a bidirectional enzyme in cell homogenates, this enzyme generally acts predominantly as an 11-ketosteroid reductase $(11 \mathrm{KSR})$ in intact cells, such that its primary role appears to be to regenerate cortisol from cortisone (Seckl \& Walker 2001, Michael et al. 2003). The $11 \beta \mathrm{HSD} 1$ enzyme has a higher affinity for cortisone $\left(K_{\mathrm{m}}=300 \mathrm{nmol} / \mathrm{l}\right)$ than it does for cortisol $\left(K_{\mathrm{m}}=17\right.$ $27 \mu \mathrm{mol} / \mathrm{l})$ and preferentially utilises $\operatorname{NADP}(\mathrm{H})$ as its nucleotide co-substrate. In most tissues (including 
liver), hexose-6-phosphate acts in the lumen of the smooth endoplasmic reticulum to maintain a high $\mathrm{NADPH}: \mathrm{NADP}^{+}$ratio, which favours the reductase action of $11 \beta \mathrm{HSD} 1$ (Draper et al. 2003, Atanasov et al. 2004, Banhegyi et al. 2004, Bujalska et al. 2005, McCormick et al. 2006). However, in steroidogenic gonadal cells (e.g. rat testis Leydig cells, human granulosa-lutein cells, bovine and porcine granulosa cells), $11 \beta \mathrm{HSD} 1$ exhibits predominantly $11 \beta$-dehydrogenase $(11 \beta \mathrm{DH})$ activity (Phillips et al. 1989, Ge et al. 1997, Michael et al. 1997, Ge \& Hardy 2000, Sunak et al. 2007, Thurston et al. 2007). This has been attributed to the preferential usage of NADPH for steroid biosynthesis, which could alter the NADPH:$\mathrm{NADP}^{+}$ratio in favour of the $11 \beta \mathrm{DH}$ activity of 11ßHSD1 (Michael et al. 2003, Ge et al. 2005). In contrast to the relatively low affinity, $\operatorname{NADP}(\mathrm{H})$ dependent, bidirectional 11ßHSD1 enzyme, $11 \beta \mathrm{HSD} 2$ has a relatively high affinity for cortisol $\left(K_{\mathrm{m}}=40-60 \mathrm{nmol} / \mathrm{l}\right)$, only exhibits $11 \beta \mathrm{DH}$ activity and relies solely on $\mathrm{NAD}^{+}$as its oxidant co-substrate. $11 \beta \mathrm{HSD} 2$ is expressed at its highest levels in mineralocorticoid target tissues, such as the kidney, colon and parotid salivary gland (Edwards et al. 1988, Mercer \& Krozowski 1992, Walker et al. 1992, Agarwal et al. 1994, Albiston et al. 1994, Whorwood et al. 1995).

In adult rat Leydig cells, the $11 \beta \mathrm{DH}$ activity of $11 \beta \mathrm{HSD} 1$ predominates, which coincides with increasing Leydig cell numbers and testosterone production, suggesting protection by $11 \beta \mathrm{HSD} 1$ from GC-mediated inhibition of steroidogenesis (Phillips et al. 1989, Monder et al. 1994a, Ge \& Hardy 2000). Recent reports in the rat suggest that $11 \beta \mathrm{HSD} 2$ may work with $11 \beta \mathrm{HSD} 1$ to inactivate GCs in Leydig cells (Ge et al. 2005). In the reproductive tract of the adult male rat, $11 \beta \mathrm{HSD} 1$ has been localised to the epithelium of the caput epididymidis, vas deferens, vesicular gland and penile urethra (Waddell et al. 2003), consistent with a role for $11 \beta \mathrm{HSD} 1$ in modulating GC actions within these regions. However, $11 \beta \mathrm{HSD} 1$ knockout mice are fertile, indicating that $11 \beta \mathrm{HSD} 1$ in the epididymidis cannot be critical for sperm maturation in the mouse (Seckl \& Walker 2001). It has been suggested that in the rat epididymidis, high $\mathrm{NAD}^{+}$-dependent $11 \beta \mathrm{DH}$ activities prior to puberty may enable aldosterone to activate the mineralocorticoid receptor and regulate ion and fluid transport (Pearce et al. 1986), which could also be the case in post-pubertal animals. $11 \beta \mathrm{HSD} 2$ has also been identified in the epididymal epithelium and corpus cavernosum of the adult rat penis (Waddell et al. 2003).

To date, there has been a single report showing that $11 \beta \mathrm{HSD}$ enzymes can catalyse cortisol oxidation in adult boar testicular homogenates (Claus et al. 2005), but no studies of enzyme expression or activities in the boar reproductive tract. Therefore, the aims of the current study were to characterise the expression and activities of
$11 \beta \mathrm{HSD} 1$ and $11 \beta \mathrm{HSD} 2$ in the boar testis and throughout the male reproductive tract to assess the region-specific pattern of GC metabolism in these tissues.

\section{Materials and Methods}

\section{Tissue collection and storage}

Boar liver, kidneys, testes and reproductive tracts were obtained from commercial boars (crosses of White Pietrain, Large White, Landrace, and Duroc breeds) at slaughter. All boars were proven breeders ( $>22$ weeks of age) and were being culled for meat products in accordance with the requirements of the UK Meat and Livestock Commission. (Boar age was confirmed by the abattoir operator and by the assessment of testis size). Liver, kidneys, testes and reproductive tracts were transported on ice to the laboratory where each individual tissue was dissected out, aliquoted into $1 \mathrm{~cm}^{3}$ segments, and either used fresh or snap frozen and stored at $-80{ }^{\circ} \mathrm{C}$ until use. All studies were conducted on tissues from at least three independent boars.

\section{PCR}

Total RNA was extracted from 30 mg wet weight of each tissue using the RNeasy Mini Kit (Qiagen Ltd) according to the manufacturer's instructions. The integrity of the total RNA extracts was assessed in all samples by visualising (and amplifying) $18 \mathrm{~S}$ rRNA transcripts. Total RNA was then reverse transcribed using an oligo-dT primer, and $5 \mu$ firststrand cDNA was used as a template in a PCR using primers specific for porcine hsd11b1and hsd11b2 (Table 1). All primers were designed using Primer3 (http://frodo.wi.edu/ cgi-bin/primer3) and sequences of porcine hsd11b1and hsd11b2 obtained from GenBank (accession numbers NM_214248 and NM_213913 respectively; Table 1). The $18 \mathrm{~S}$ oligonucleotide primers were designed based on the human $18 \mathrm{~S}$ sequence (accession number M10098) using nucleotide sequences known to be fully conserved among human, rat, mouse and rabbit (Table 1).

PCR was performed using the Taq PCR Core Kit (Qiagen). Cycling parameters for PCR were as follows for all amplified cDNAs: an initial denaturation step of 5 min at $94{ }^{\circ} \mathrm{C}$, followed by 35 cycles of $30 \mathrm{~s}$ at $94{ }^{\circ} \mathrm{C}$, $30 \mathrm{~s}$ at $55^{\circ} \mathrm{C}$ and $1 \mathrm{~min}$ at $72{ }^{\circ} \mathrm{C}$, and a final extension step of $5 \mathrm{~min}$ at $72{ }^{\circ} \mathrm{C}$. Ten microlitres of each PCR were run on a $1.6 \%(\mathrm{w} / \mathrm{v})$ agarose gel to visualise PCR products. PCR products from kidney, liver and testis were isolated and subjected to the dideoxy-DNA sequencing method to confirm specificity.

\section{Western blot analysis}

All tissues were lysed on ice in radioimmunoprecipitation buffer containing $50 \mathrm{mmol} / \mathrm{l}$ Trizma and $154 \mathrm{mmol} / \mathrm{l}$ $\mathrm{NaCl}(\mathrm{pH} 7.4)$ with a protease inhibitor cocktail (Mini- 
Table 1 Details of the PCR primer sequences, regions of the target genes that each set of primers will amplify and the expected product sizes for the PCR amplicons.

\begin{tabular}{llcc}
\hline Primer & \multicolumn{1}{c}{ Sequence } & Region (bp) & Product size (bp) \\
\hline $11 \beta \mathrm{HSD} 1$ & Forward 5'-CGCTCTGTATCCTCGGTCTC-3' & $709-720$ & 394 \\
& Reverse 5'-GTGTAGCGTAGAGTGTTCGA-3' & $1102-1082$ & 23 \\
$11 \beta \mathrm{HSD} 2$ & Forward 5'-CCAGCAGGAGATATGCCATT-3' & $723-743$ & $952-932$ \\
& Reverse 5'-CTCGACGATGTCCGGATACC-3' & $862-881$ & 315 \\
$18 \mathrm{~S}$ & Forward 5'-CGATGCTCTTAGCTGAGTGT-3' & $1176-1157$ & \\
& Reverse 5'-AGTCTATGGCAGCATCAAGG-3' & \\
\hline
\end{tabular}

complete protease inhibitor, Roche). Protein concentrations were determined using the NanoDrop ND-1000 full spectrum UV/Vis spectrophotometer (NanoDrop Technologies Inc., Wilmington, DE, USA). Protein from boar liver, kidney, testis and reproductive tract was diluted with sample buffer to give a final loading concentration of $25 \mu \mathrm{g}$ total protein per $25 \mu \mathrm{l}$ and separated by SDS-PAGE on a $12.5 \%(\mathrm{w} / \mathrm{v})$ polyacrylamide gel before being transferred to a polyvinylidine difluoride membrane using a TE22 Mighty Small transphor tank wet transfer unit (Hoefer, San Francisco, CA, USA).

The membranes were incubated overnight at $4{ }^{\circ} \mathrm{C}$ in a $1 / 1000$ dilution of sheep anti-human $11 \beta \mathrm{HSD} 1$ or sheep anti-human $11 \beta \mathrm{HSD} 2$ polyclonal antibody each in PBS-T containing $5 \%(\mathrm{w} / \mathrm{v})$ non-fat milk. $11 \beta \mathrm{HSD}$ antibodies were raised commercially against the human $11 \beta \mathrm{HSD} 1$ protein sequence (amino acids 1933 ) and the human $11 \beta \mathrm{HSD} 2$ protein sequence (amino acids 137-160 and 334-358; The Binding Site Ltd, Birmingham, UK). Sequence alignment confirmed that the human peptide sequences against which the $11 \beta \mathrm{HSD} 1$ and $11 \beta \mathrm{HSD} 2$ antibodies were directed shared 100, 82.6 and $92 \%$ amino acid identities with the corresponding regions of porcine $11 \beta \mathrm{HSD} 1$ and $11 \beta \mathrm{HSD} 2$ respectively. Membranes were incubated with a 1/10 000 dilution of rabbit anti-sheep IgG secondary antibody conjugated to horseradish peroxidase (HRP; Abcam, Cambridge, UK) in PBS-T containing 5\% (w/v) non-fat milk. $11 \beta \mathrm{HSD}$ proteins were visualised by incubating with ECL detection reagents (Amersham Biosciences) and exposed onto Hyperfilm ECL. To confirm integrity of protein transfer, membranes were stripped and re-probed for $\beta$-actin using a polyclonal $\beta$-actin antibody (Abcam) at a dilution of $1 / 5000$.

In order to confirm the number of protein bands within each lane exhibiting $11 \beta \mathrm{HSD}$ activity, samples were also resolved under non-denaturing, non-reducing conditions, such that proteins remained in a native polymerised state. Protein preparations from boar liver, kidney, testis and reproductive tract were each diluted with a non-reducing sample buffer to a final loading concentration of $25 \mu \mathrm{g}$ total protein per $25 \mu \mathrm{l}$. Proteins were then resolved on a non-reducing, $12.5 \%(\mathrm{w} / \mathrm{v})$ polyacrylamide gel. Resolved gels were incubated for up to $24 \mathrm{~h}$ at room temperature with a reaction mixture comprising $0.01 \mathrm{~mol} / / \mathrm{l}$ sodium phosphate buffer $(\mathrm{pH} 7.4)$ containing cortisol $(0.007 \mathrm{mg} / \mathrm{ml}$; Sigma), nitroblue tetrazolium (NBT; $0.147 \mathrm{mg} / \mathrm{ml}$; Sigma), nicotinamide $\left(0.234 \mathrm{mg} / \mathrm{ml}\right.$; Sigma) and either $\mathrm{NADP}^{+}$or $\mathrm{NAD}^{+}$(each at a final concentration of $1.055 \mathrm{mg} / \mathrm{ml}$ ). The presence of functional $11 \beta \mathrm{HSD}$ protein was localised within each lane by the deposition of purple formazan bands, formed by the sequential transfer of reducing equivalents from the cortisol to the NBT via the pyridine dinucleotide cofactor $\left(\mathrm{NADP}^{+} / \mathrm{NAD}^{+}\right)$.

\section{Immunohistochemistry (IHC)}

The concurrent assessments of enzyme activity (described below) revealed the highest $11 \beta \mathrm{HSD}$ enzyme activities in boar testis, caput epididymidis and bulbourethral gland. Hence, only these three tissues were subjected to IHC to localise the expression of $11 \beta \mathrm{HSD} 1$ and $11 \beta \mathrm{HSD} 2$ proteins. Freshly isolated biopsies $\left(1 \mathrm{~cm}^{3}\right)$ of boar testis and reproductive tract tissues were fixed in BDH Gurr neutral buffered formalin (VWR International, Poole, UK) for 1 month. Each biopsy was embedded in a paraffin block and a ribbon (approximately six sections) of $6-7 \mu \mathrm{m}$ sections was cut on a microtome. Prior to use, the paraffinembedded sections mounted on Polysine slides (VWR) were dewaxed and rehydrated by successively placing the slides in $100 \%(\mathrm{v} / \mathrm{v})$ xylene, $100 \%(\mathrm{v} / \mathrm{v})$ ethanol, $70 \%(\mathrm{v} / \mathrm{v})$ ethanol and $\mathrm{dd}_{2} \mathrm{O}$ to complete rehydration. Endogenous peroxidase activity was then inhibited by washing with $0.1 \mathrm{~mol} / \mathrm{l}$ sodium phosphate buffer $\left(\mathrm{Na}_{2} \mathrm{HPO}_{4} \cdot 2 \mathrm{H}_{2} \mathrm{O}\right.$ and $\mathrm{NaH}_{2} \mathrm{PO}_{4} \cdot 2 \mathrm{H}_{2} \mathrm{O}$; Fluka, Biochemica, Germany) containing 20\% (v/v) methanol, $0.3 \%(\mathrm{v} / \mathrm{v})$ Triton X-100 Sigma-Ultra (Sigma) and 1\% $(\mathrm{v} / \mathrm{v})$ hydrogen peroxide (Sigma). Non-specific binding was blocked by a 2-h incubation in blocking buffer $(0.1 \mathrm{~mol} / \mathrm{l}$ sodium phosphate buffer, $0.3 \%(\mathrm{v} / \mathrm{v})$ Triton $\mathrm{X}-100$ and $1 \%(\mathrm{w} / \mathrm{V})$ BSA fraction $\mathrm{V} \geq 96 \%$ (Sigma)). The sections were incubated overnight at $4{ }^{\circ} \mathrm{C}$ with primary antibody diluted to a working titre of $1 / 250$ with blocking buffer. On day 2, the sections were incubated for $2 \mathrm{~h}$ at room temperature with fluorescent secondary antibody in blocking buffer before a 5-min incubation in the dark with 4',6-diamidino-2-phenylindole, diluted to a working titre of $1 / 5000$ with $0.1 \mathrm{~mol} / \mathrm{l}$ phosphate buffer. Coverslips were mounted 
with the use of Vectorshield (Vector Laboratories Inc., Burlingame, CA, USA) and all sections were stored at $4{ }^{\circ} \mathrm{C}$ in the dark until visualisation.

\section{1ßHSD bioactivity}

Porcine liver, kidney, testis and regions of reproductive tract were each homogenised separately in $18 \mathrm{ml}$ hypotonic Tris-EDTA lysis buffer $(0.6 \mathrm{~g} / \mathrm{l}$ Trizma, $0.3 \mathrm{~g} / \mathrm{l}$ $\mathrm{MgCl}_{2}, 0.6 \mathrm{~g} / \mathrm{EDTA}$ ) followed by the addition of $2 \mathrm{ml}$ potassium chloride $(1.5 \mathrm{mmol} / \mathrm{l})$ to restore isotonicity. Homogenates were centrifuged at $1000 \mathrm{~g}$ for $20 \mathrm{~min}$ at $4{ }^{\circ} \mathrm{C}$ and $1 \mathrm{ml}$ volumes of supernatant were aliquoted for storage at $-20^{\circ} \mathrm{C}$. Protein concentrations for each homogenate were determined as above. Prior to assay, tissue homogenates were diluted (using lysis buffer and $\mathrm{KCl}$ ) to ensure that the final protein concentration for each tissue was $<1500 \mu \mathrm{g}$ protein/ml. In pilot assays conducted using the three tissues with the highest $11 \beta \mathrm{HSD}$ enzyme activities (testis, caput epididymidis and bulbourethral gland), we had confirmed that at the selected substrate concentrations, the levels of substrate metabolism over $24 \mathrm{~h}$ increased linearly in proportion to protein concentration across the range of $0-1500 \mu \mathrm{g}$ protein $/ \mathrm{ml}$.

Each enzyme activity was assayed in triplicate in a final volume of $1 \mathrm{ml}$ PBS per tube containing $10 \%(\mathrm{v} / \mathrm{v})$ tissue homogenate and $0.4 \mathrm{mmol} / \mathrm{l}$ pyridine nucleotide co-substrates $\pm 10 \mathrm{mmol} / \mathrm{l}$ glucose-6-phosphate (G6P) as appropriate. Measurements of net $11 \mathrm{KSR}$ and net $11 \beta \mathrm{DH}$ activities were initiated by the addition of $0.5 \mu \mathrm{Ci}(11.11 \mathrm{nmol} / \mathrm{l})\left[1,2,(n){ }^{3} \mathrm{H}\right]$ cortisone or $0.5 \mu \mathrm{Ci}$ (7.25 nmol/l) $\left[1,2,6,7-{ }^{3} \mathrm{H}\right]$ cortisol respectively.

Following a 24-h incubation in a shaking water bath at $37^{\circ} \mathrm{C}, 2 \mathrm{ml}$ ice-cold chloroform was added to each tube. Tubes were vortexed and subsequently centrifuged at $3000 \mathrm{~g}$ for $20 \mathrm{~min}$ at $4{ }^{\circ} \mathrm{C}$. The aqueous phase was aspirated and the extracts were evaporated to dryness at $45^{\circ} \mathrm{C}$ under nitrogen. Steroid residues were resuspended in $30 \mu \mathrm{l}$ ethyl acetate containing $1 \mathrm{mmol} / \mathrm{l}$ cortisol and $1 \mathrm{mmol} / \mathrm{l}$ cortisone. $\left[{ }^{3} \mathrm{H}\right]$ cortisol and $\left[{ }^{3} \mathrm{H}\right]$ cortisone were resolved by thin layer chromatography in an atmosphere of 92:8 (v/v) chloroform:95\% (v/v) ethanol, and $11 \beta \mathrm{HSD}$ activities were quantified using a Bioscan System 200 radiochromatogramme scanner (Lablogic, Sheffield, UK).

\section{1ßHSD enzyme kinetic analysis}

The kinetics of cortisol-cortisone metabolism were assessed in homogenates of testis, caput epididymidis and bulbourethral gland from three boars using radiometric conversion assays as described above. Initial time course assays confirmed linear rates of generation of products over time up to $4 \mathrm{~h}$ using either $\left[{ }^{3} \mathrm{H}\right]$ cortisone or $\left[{ }^{3} \mathrm{H}\right]$ cortisol, each at a final concentration of $100 \mathrm{nmol} / \mathrm{l}$. Tissue homogenates were subsequently incubated for $2 \mathrm{~h}$ at $37^{\circ} \mathrm{C}$ in $1 \mathrm{ml}$ PBS containing $\left[{ }^{3} \mathrm{H}\right]$ cortisone $(12.5,30,60$ and $100 \mathrm{nmol} / \mathrm{l}$ ) plus $0.4 \mathrm{mmol} / \mathrm{l} \mathrm{NADPH}$ and $10 \mathrm{mmol} / \mathrm{l}$ G6P, or with $\left[{ }^{3} \mathrm{H}\right]$ cortisol $(6.8,10,30,60,100,300$ and

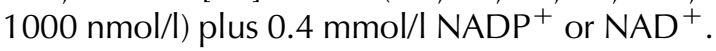

\section{Statistical analyses of data}

All statistical tests were performed using GraphPad Prism 4 statistical software, version 4.01 (GraphPad Inc., San Diego, CA, USA). Each data set was initially subjected to Kolmogorov-Smirnov tests to confirm that data conformed to Gaussian (normal) frequency distributions. For $K_{\mathrm{m}}$ and $V_{\text {max }}$ estimates made under first-order kinetic conditions, the estimates of each kinetic parameter were compared between tissues using one-way ANOVA followed by application of the post hoc Bonferroni multiple comparison test, where appropriate. A $P$ value $<0.05$ was accepted as statistically significant in all tests.

\section{Results}

\section{Expression of hsd11b1 and hsd11b2 mRNA}

Both $11 \beta \mathrm{HSD} 1$ and $11 \beta \mathrm{HSD} 2 \mathrm{mRNA}$ transcripts were expressed in boar liver, kidney, testis and all reproductive tract tissues (Fig. 1). When sequenced, all PCR products were found to have $100 \%$ identity with previously published sequences for porcine $11 \beta \mathrm{HSD} 1$ and $11 \beta \mathrm{HSD} 2$.

\section{Expression of hsd11b1 and hsd11b2 proteins}

$11 \beta \mathrm{HSD} 1$ and $11 \beta \mathrm{HSD} 2$ protein bands were detected in boar liver, kidney, testis and all regions of the male reproductive tract (Fig. 2). The $11 \beta \mathrm{HSD} 1$ antibody recognised a major band at $32 \mathrm{kDa}$ (the expected size) and a minor band at $44 \mathrm{kDa}$ in boar liver and kidney. However, only the $44 \mathrm{kDa}$ band was seen in boar testis and all reproductive tract tissues (Fig. 2C). The $11 \beta \mathrm{HSD} 2$ antibody consistently recognised a single protein band at $44 \mathrm{kDa}$ (the expected size) in boar testis and reproductive tract regions (Fig. 2B). For all tissues, a single enzymatic protein band was visualised by incubation of non-reducing gels with NBT plus either $\mathrm{NADP}^{+}$or $\mathrm{NAD}^{+}$(data not shown).

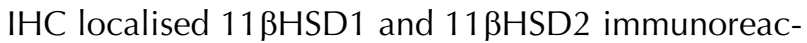
tivity to the interstitial tissues of the boar testis, caput epididymidis duct and bulbourethral gland (Fig. 3).

\section{$11 \beta H S D 1$ and 11ßHSD2 bioactivities}

In initial screens for $11 \beta \mathrm{HSD}$ enzyme activities, performed over $24 \mathrm{~h}$ at limiting substrate concentrations (to maximise the likelihood of observing steroid substrate metabolism), homogenates of boar testis, bulbourethral gland and penile urethra all demonstrated pronounced $\mathrm{NADP}(\mathrm{H})$ - and $\mathrm{NAD}^{+}$-dependent cortisol-cortisone 


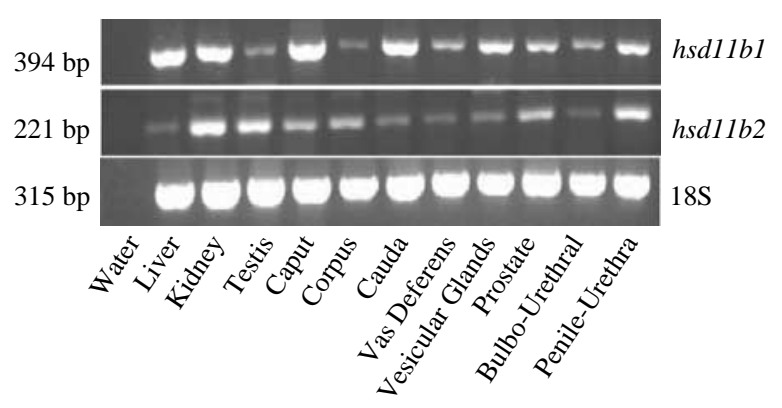

Figure $111 \beta \mathrm{HSD} 1$ and $11 \beta \mathrm{HSD} 2 \mathrm{mRNA}$ expression in the liver, kidney, testis and reproductive tract regions of boars. Amplicons were generated using primers specific for $h s d 11 b 1$, hsd $11 b 2$ and $18 \mathrm{~S}$ cDNA, and all bands observed in all tissues with each primer set are of the correct predicted size: 394, 221 and 315 bp respectively. The figure shows typical RT-PCR product gels in which the tissue-specific mRNA expression profile was representative of three boars.

interconversion (Figs 4 and 5). The only other region of boar reproductive tract with a substantial $11 \beta \mathrm{HSD}$ enzyme activity was the caput epididymidis, which exhibited 11KSR activity (Fig. 4). In all other regions of the boar reproductive tract, enzyme activities in these

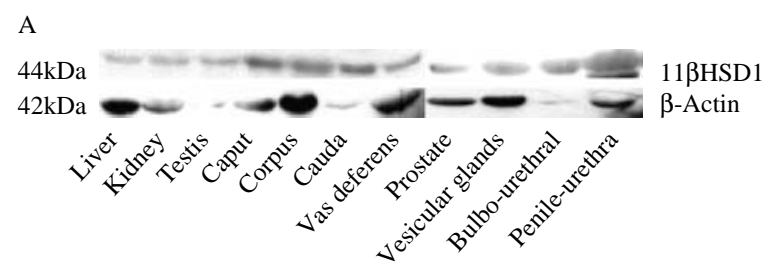

B

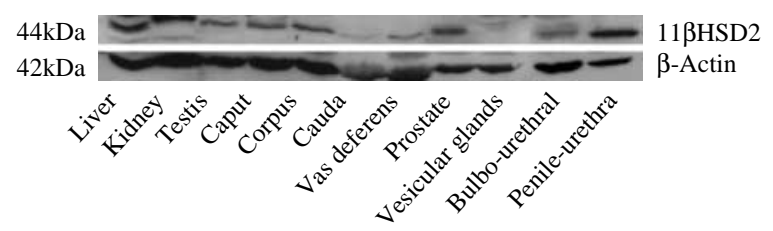

C

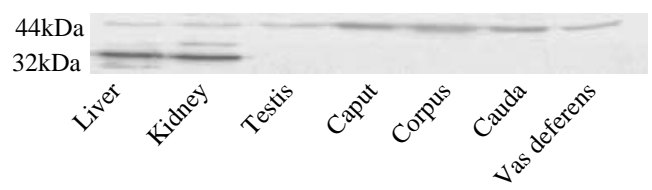

Figure $211 \beta \mathrm{HSD} 1$ and $11 \beta \mathrm{HSD} 2$ protein expression in the liver, kidney, testis and reproductive tract regions of boars. Western blots were probed with antibodies raised against peptide sequences in $11 \beta \mathrm{HSD} 1$ (panels A and C), $11 \beta \mathrm{HSD} 2$ (panel B) and $\beta$-actin (panels A and B). Panel $C$ shows the pattern of immunoreactive proteins recognised in tissue protein preparations by the polyclonal anti-11 $\beta$ HSD1 antibody; the antibody recognised a major protein at $32 \mathrm{kDa}$ in boar liver and kidney (with minor bands recognised between 32 and $44 \mathrm{kDa}$ ), whereas the same antibody recognised a single $44 \mathrm{kDa}$ protein in the boar testis and regions of reproductive tract. Each panel shows typical western blots in which the tissue-specific protein expression profile was representative of three boars. initial assays were at or below our assay detection limit $(\leq 0.4 \mathrm{pmol}$ product $/ \mathrm{mg}$ protein. $24 \mathrm{~h}$ ) such that these regions did not merit further investigation (Figs 4 and 5).

In terms of positive control tissues, the highest level of $\mathrm{NADPH}$-dependent $11 \mathrm{KSR}$ activity was observed in boar liver homogenates co-incubated with $10 \mathrm{mmol} / \mathrm{l} \mathrm{G6P}$ (Fig. 4), which also showed relatively high $\mathrm{NADP}^{+}$. dependent $11 \beta \mathrm{DH}$ activities (Fig. 5A). The major $11 \beta \mathrm{HSD}$ activity in boar kidney homogenates was the $\mathrm{NAD}^{+}$-dependent oxidation of cortisol (Fig. 5B), although this tissue also displayed moderate levels of NADP $^{+}$-dependent cortisol oxidation (Fig. 5A).

\section{1ßHSD enzyme kinetics}

In light of the results described above, all subsequent assessments of enzyme activity were performed in boar testis, caput epididymidis and bulbourethral gland. In order to enable valid comparisons of enzyme activity parameters between tissues, we conducted kinetic analyses of cortisol-cortisone interconversion under firstorder kinetic conditions. The reciprocal rates of substrate metabolism (in pmol product/h) were plotted against the reciprocal of the substrate concentrations (in $\mathrm{nmol} / \mathrm{l}$ ) to derive a linear Lineweaver-Burk plot for each enzyme activity in each tissue (Figs 6 and 7), from which we were able to estimate the maximal enzyme velocities $\left(V_{\max }\right)$ and the Michaelis-Menten constants $\left(K_{\mathrm{m}}\right.$ : the concentrations of steroid substrate at which half maximal velocity was attained; Tables 2 and 3). For each enzyme activity, estimates of $V_{\max }$ (the reciprocal of the $y$-axis intercept) and $K_{\mathrm{m}}$ (the negative reciprocal of the $x$-axis intercept) were derived by rearranging the equation $1 / V=m .1 / S+c$ (where $V=$ velocity, $m=$ gradient, $S=$ the substrate concentration and $c=$ the intercept on the $y$-axis). For a given pyridine nucleotide cofactor, each of the estimated enzyme parameters did not differ significantly between homogenates of boar testis, caput epididymides or bulbourethral glands. While the $K_{\mathrm{m}}$ estimates for all three enzyme activities were similar, ranging from 132 to $443 \mathrm{nmol} / \mathrm{l}$, the $V_{\max }$ estimates for the rates of cortisol inactivation in the presence of $\mathrm{NADP}^{+}$and $\mathrm{NAD}^{+}(12.2-$ $19.0 \mathrm{pmol}$ cortisone/h and 10.0-11.2 pmol cortisone/h respectively) were consistently higher than the maximal $11 \mathrm{KSR}$ enzyme velocities in the presence of NADPH (1.7$2.7 \mathrm{pmol}$ cortisol/h; Tables 2 and 3).

\section{Discussion}

Endogenous GCs (cortisol and corticosterone) have established roles in reproductive physiology, which are modulated in several reproductive tissues by one or more of the cloned $11 \beta \mathrm{HSD}$ enzymes (reviewed by Michael et al. 2003). In the male, GCs are known to exert a range of adverse effects on Leydig cell function (Bambino \& Hsueh 1981, Monder et al. 1994b, Gao 

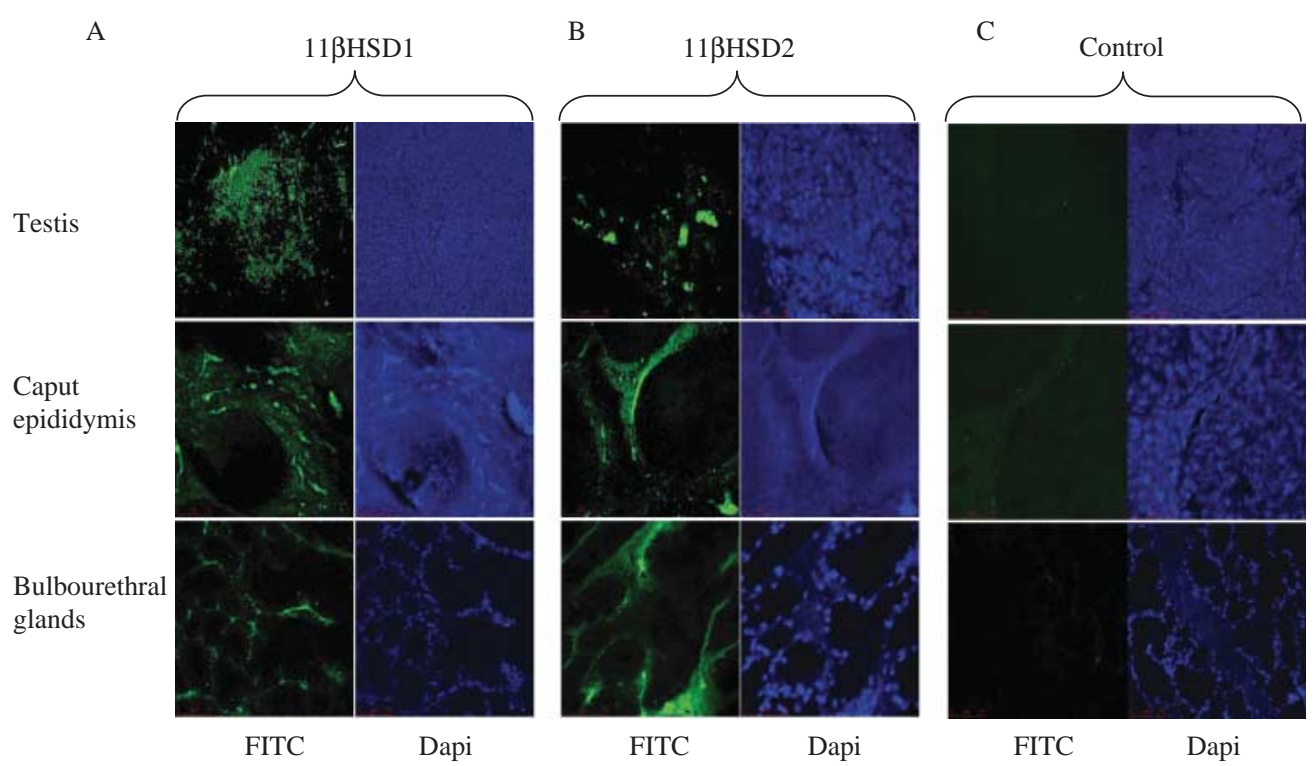

Figure 3 11HSD1 and 11HSD2 protein localisation in boar testis, caput epididymidis and bulbourethral gland. Immunofluorescence was clearly seen in interstitial areas of the testis, in the tissue comprising the caput epididymidis duct, and in the epithelium of the bulbourethral glands when all tissues were probed for $11 \beta \mathrm{HSD} 1$ (panel A) and 11ßHSD2 (panel B). As expected, no fluorescence was observed when primary antibodies were omitted as a negative control (panel C). Each panel shows typical immunofluorescence in which the tissue-specific protein localisation is representative of three boars.

et al. 1997) and, with specific reference to the boar, they have recently been shown to induce apoptosis in spermatogonia (Claus et al. 2005). However, the basic understanding of GC metabolism and actions in the boar testis and reproductive tract is very limited. This study found that although $11 \beta \mathrm{HSD} 1$ and $11 \beta \mathrm{HSD} 2 \mathrm{mRNA}$ and protein were co-expressed in boar testis and all regions of the male reproductive tract, rates of cortisol-cortisone interconversion were at or below the enzyme activity assay detection limit in all tissues apart from the testis, caput epididymidis, bulbourethral gland and penile urethra. In these tissues, we have now characterised, for the first time, the balance and kinetics of cortisolcortisone metabolism by $\mathrm{NADP}(\mathrm{H})$ - and $\mathrm{NAD}^{+}$-dependent $11 \beta \mathrm{HSD}$ enzymes.

While the $11 \beta \mathrm{HSD} 2$ antibody recognised a single immunoreactive protein in all tissues which migrated at the anticipated size of $44 \mathrm{kDa}$ (Lange et al. 2003), the anti-11 $\beta$ HSD1 antibody recognised two protein bands (at 32 and $44 \mathrm{kDa}$ ) in boar liver and kidney, and only the $44 \mathrm{kDa}$ protein in boar testis and all reproductive tract tissues. This finding accords with a previous study which found that anti-11 $\beta \mathrm{HSD} 1$ antibodies recognised proteins that are $14 \mathrm{kDa}$ larger than anticipated in the male rat reproductive tract (Waddell et al. 2003). The larger size products in the rat were suggested to represent glycosylated forms of the $11 \beta \mathrm{HSD} 1$ protein (Waddell et al. 2003). Certainly, the $44 \mathrm{kDa}$ band observed in the current study could result from post-translational modifications of porcine $11 \beta \mathrm{HSD} 1$. More importantly, when we assessed functional $11 \beta \mathrm{HSD}$ protein bands under non-reducing, non-denaturing conditions, we observed a single band of $\mathrm{NADP}^{+}$-dependent $11 \beta \mathrm{HSD}$ bioactivity in proteins prepared from each tissue.

Published studies of the rat testis have localised the cloned $11 \beta \mathrm{HSD}$ enzymes to the interstitial Leydig cells of the testis (Phillips et al. 1989, Ge et al. 2005). In the current immunohistochemical studies, both $11 \beta \mathrm{HSD} 1$

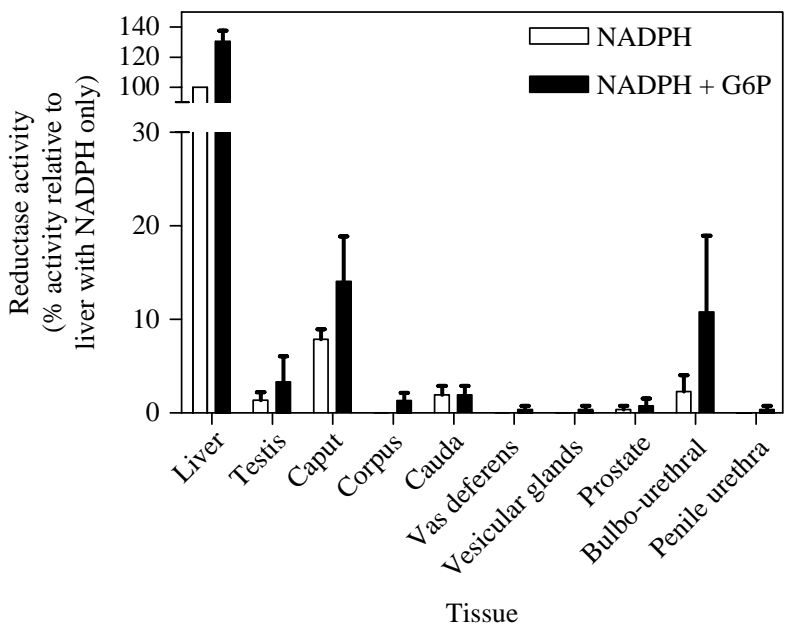

Figure $411 \mathrm{KSR}$ activities in the liver, testis and reproductive tract tissues of boars. Using homogenates of each tissue, net $11 \mathrm{KSR}$ activities were measured in the presence of $0.4 \mathrm{mmol} / \mathrm{I} \mathrm{NADPH}$ either in the absence (open bars) or in the presence (closed bars) of $10 \mathrm{mmol} / \mathrm{l} \mathrm{G6P.}$ All data are presented as the mean +S.E.M. enzyme activities in tissue homogenates from three independent boars, expressed as a percentage of the $11 \mathrm{KSR}$ activity measured in parallel in homogenates of boar liver incubated with $0.4 \mathrm{mmol} / \mathrm{INADPH}$ (but without $10 \mathrm{mmol} / / \mathrm{G} 6 \mathrm{P}$ ). The reference mean hepatic $11 \mathrm{KSR}$ activity across these three assays equated to $5.2 \mathrm{pmol}$ cortisol $/ \mathrm{mg}$ protein. $24 \mathrm{~h}$. 

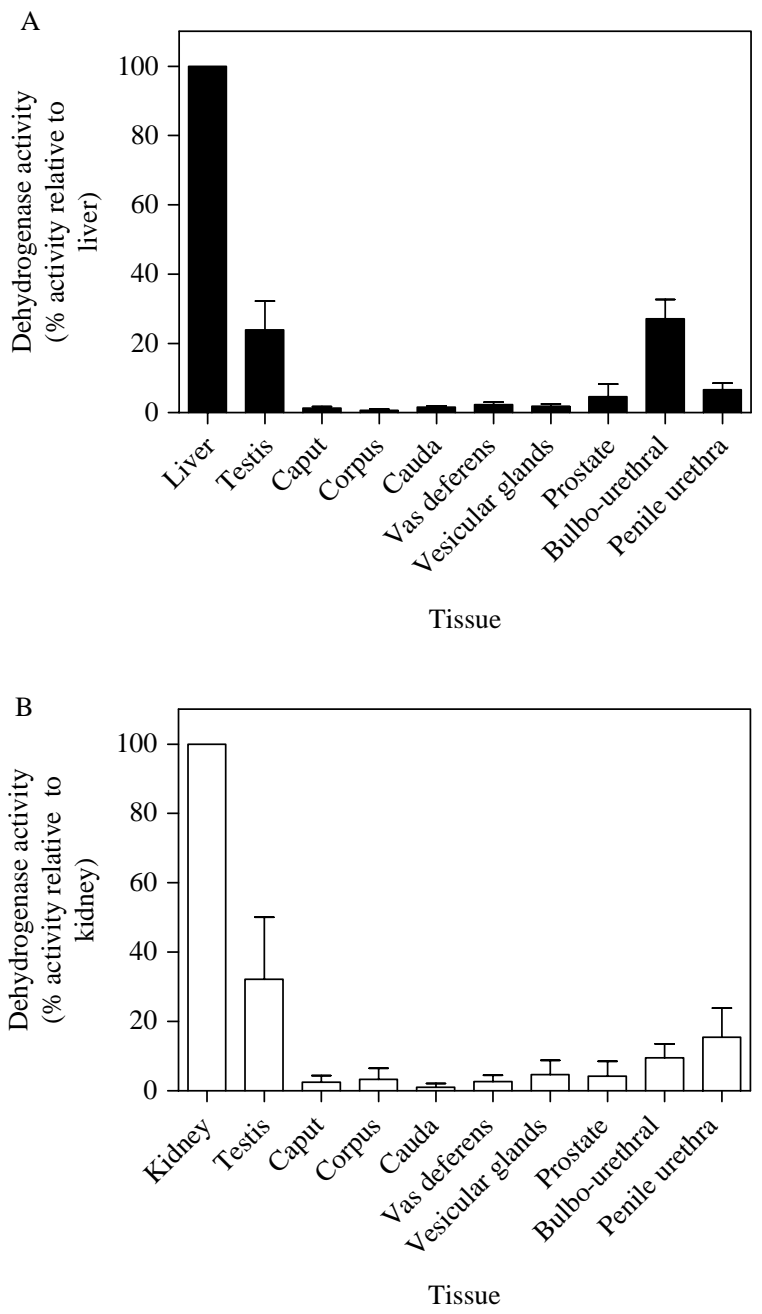

Figure $511 \beta$-Dehydrogenase activities in the liver, kidneys, testis and reproductive tract tissues of boars. Using homogenates of each tissue, net $11 \beta$-dehydrogenase activities were measured in the presence of either $0.4 \mathrm{mmol} / \mathrm{I} \mathrm{NADP}^{+}$(panel A) or $0.4 \mathrm{mmol} / \mathrm{I} \mathrm{NAD}^{+}$(panel B). All data are presented as the mean+S.E.M. enzyme activities in tissue homogenates from five independent boars, expressed as a percentage of the $11 \beta \mathrm{DH}$ activities measured in boar liver homogenates incubated with $\mathrm{NADP}^{+}$(panel A) or in boar kidney homogenates incubated with $\mathrm{NAD}^{+}$(panel B). The reference mean $11 \beta \mathrm{DH}$ activities across these five assays equated to $12.4 \mathrm{pmol}$ cortisone/mg protein.24 $\mathrm{h}$ and $16.2 \mathrm{pmol}$ cortisone/mg protein. $24 \mathrm{~h}$ for panels $\mathrm{A}$ and $\mathrm{B}$ respectively.

and $11 \beta \mathrm{HSD} 2$ proteins localised to the interstitial tissue of the boar testis, consistent with expression in the steroidogenic interstitial Leydig cells. In terms of the reproductive tract, both $11 \beta \mathrm{HSD} 1$ and $11 \beta \mathrm{HSD} 2$ proteins were also co-expressed in the caput epididymidis duct and bulbourethral gland. The bulbourethral gland consists of mucus-secreting epithelium that lines the acini of this gland. While we observed localisation of both $11 \beta \mathrm{HSD} 1$ and $11 \beta \mathrm{HSD} 2$ to this epithelium, the mucus itself appeared to be devoid of staining.

Kinetic analysis of the $11 \beta \mathrm{HSD}$ enzyme activities in the boar testis, caput epididymidis and bulbourethral gland

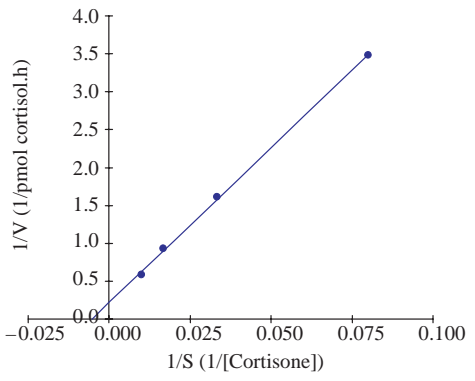

Figure 6 Kinetic analysis of 11KSR activity in a boar testis homogenate. A representative Lineweaver-Burk plot for NADPH-dependent $11 \mathrm{KSR}$ activity in one boar testis homogenate, from which $K_{\mathrm{m}}$ and $V_{\max }$ were estimated for that individual animal. This method of analysis was used to derive estimates of $K_{\mathrm{m}}$ and $V_{\max }$ for homogenates of testis, caput epididymidis and bulbourethral gland from three boars.

generated $K_{\mathrm{m}}$ values for the boar enzymes, which were noticeably different from those previously published for the rat and human $11 \beta \mathrm{HSD}$ enzymes. Specifically, the $K_{\mathrm{m}}$ estimates for the $\mathrm{NADP}^{+}$-dependent oxidation of cortisol (237-443 nmol/l) were two orders of magnitude lower in all three tissues than published $K_{\mathrm{m}}$ values for the rat and human $11 \beta \mathrm{HSD} 1$ enzymes. This relatively high-affinity $\mathrm{NADP}^{+}$-dependent activity could result from allosteric regulation and/or some other functional modification of the boar $11 \beta \mathrm{HSD} 1$ protein, serving to increase the enzyme affinity for cortisol. A post-translational modification of the boar $11 \beta \mathrm{HSD} 1$ protein would certainly be consistent with the increased mass of the $11 \beta \mathrm{HSD} 1$ protein band in the Western blots. Alternatively, we cannot exclude the possibility of a novel high-affinity $\mathrm{NADP}^{+}$-dependent $11 \beta \mathrm{DH}$ enzyme in the boar tract, given that the existence of such an enzyme has previously been suggested (Gomez-Sanchez et al. 1997).

With regard to $\mathrm{NAD}^{+}$-dependent cortisol metabolism, the estimated $K_{\mathrm{m}}$ values in the present study (154-226 nmol/l) were slightly higher than anticipated based on the published values for the rat and human $11 \beta$ HSD2 enzymes ( $40-60 \mathrm{nmol} / \mathrm{l})$. Hence, in these boar tissues, there may be a compound acting as a competitive inhibitor of $11 \beta \mathrm{HSD} 2$, and so elevating the $K_{\mathrm{m}}$ for $\mathrm{NAD}^{+}$-dependent cortisol metabolism. In support of this suggestion, a number of physiological compounds have been reported to exert competitive inhibition of $11 \beta \mathrm{HSD} 2$ activity in a variety of cell types (Souness et al. 1995, Ferrari et al. 1996, Gomez-Sanchez et al. 1996, Morita et al. 1996, Latif et al. 2005).

In the rat testis, GCs are known to inhibit testosterone biosynthesis and to induce Leydig cell apoptosis (Bambino \& Hsueh 1981, Monder et al. 1994b, Gao et al. 1997). It has therefore been suggested that $11 \beta \mathrm{HSD} 1$ acts as a predominant $\mathrm{NADP}^{+}$-dependent $11 \beta \mathrm{DH}$ in adult rat Leydig cells as a mechanism to protect against the deleterious effects of GCs (Phillips et al. 1989, Ge \& Hardy 2000). Recently, $11 \beta \mathrm{HSD} 2$ has been shown to contribute to this protective system in the 

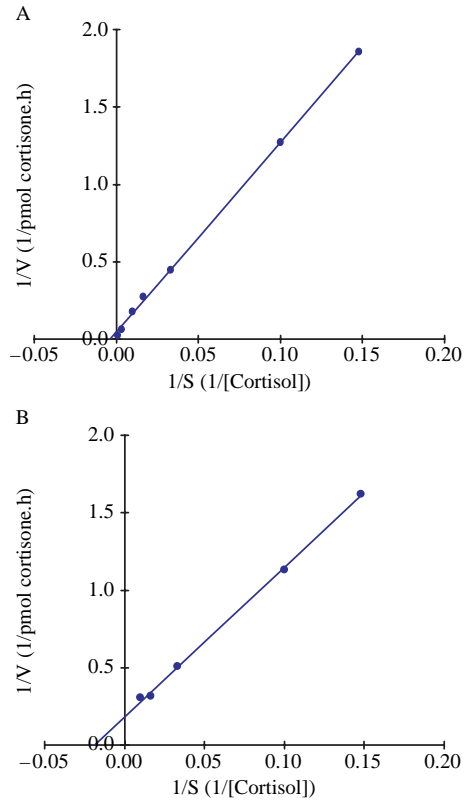

Figure 7 Kinetic analysis of $11 \beta \mathrm{DH}$ activities in a boar testis homogenate. A representative Lineweaver-Burk plot for net oxidation of cortisol in the presence of $0.4 \mathrm{mmol} / / \mathrm{NADP}^{+}$(panel A) or $\mathrm{NAD}^{+}$(panel B) in one boar testis homogenate, from which $K_{\mathrm{m}}$ and $V_{\max }$ were estimated for that individual animal. This method of analysis was used to derive estimates of $K_{\mathrm{m}}$ and $V_{\max }$ in the presence of each pyridine nucleotide cofactor for homogenates of testis, caput epididymidis and bulbourethral gland from three boars.

rat testis (Ge et al. 2005), although levels of $\mathrm{NAD}^{+}$dependent $11 \beta \mathrm{HSD} 2$ activity appear to be $<1 \%$ of the $\mathrm{NADP}^{+}$-dependent $11 \beta \mathrm{HSD}$ activity in adult rat Leydig cells. Following an initial report of $\mathrm{NADP}^{+}$-dependent inactivation of cortisol in the adult boar testis (Claus et al. 2005), we now report that boar testes actually co-express $11 \beta \mathrm{HSD} 1$ and $11 \beta \mathrm{HSD} 2 \mathrm{mRNA}$ transcripts and proteins, and that both of these enzymes appear to be operational in catalysing the interconversion of cortisol with its inert 11-ketosteroid metabolite, cortisone. While the coexpression of both cloned $11 \beta \mathrm{HSD}$ enzymes appears to be common to boar and rat testes, in contrast to the strong preference for $\mathrm{NADP}^{+}$reported for rat Leydig cells (Ge et al. 1997, Ge et al. 2005), studies of enzyme activities in boar testis homogenates established that the $V_{\text {max }}$ for the $\mathrm{NAD}^{+}$-dependent oxidation of cortisol does not differ significantly from the $V_{\max }$ estimated in the presence of $\mathrm{NADP}^{+}$. This difference in enzyme activities between boar testis homogenates and rat Leydig cells could simply reflect morphological and/or physiological differences between the two species, and in this context, it may be relevant to note that in the boar testis, Leydig cells account for as much as $30 \%$ of the testis by volume (as compared with $<10 \%$ in the rat testis). Alternatively, the overall balance of cortisol-cortisone metabolism in homogenates of boar testis may have been influenced by expression of $11 \beta \mathrm{HSD}$ enzymes in cells other than the Leydig cells (e.g. in peritubular myoid cells, Sertoli cells or spermatogonia/spermatocytes/spermatozoa at various developmental stages).

The caput epididymides are involved in rete testis fluid reabsorption. Hence, we would speculate that in this duct, the high $\mathrm{NADP}(\mathrm{H})$-dependent $11 \beta \mathrm{HSD}$ activities, which we observed in this region, may be important in modulating the potential effects of GCs on ion and fluid transport. In light of the presence of sodium-proton co-transporters, any steroidal control of sodium flux within the caput epididymidis would be expected to alter the luminal $\mathrm{pH}$ and hence affect the final maturation of sperm in this duct (Pushkin et al. 2000, Phillips \& Schultz 2002). Previous studies have also reported a predominant 11 KSR activity in the rat cauda epididymidis (Waddell et al. 2003). Although the current study found $11 \beta \mathrm{HSD} 1$ and $11 \beta \mathrm{HSD} 2 \mathrm{mRNA}$ and protein to be co-expressed in the boar corpus and cauda epididymides, vas deferens, vesicular and prostate glands, our initial assessments of enzyme activities indicated that rates of cortisol-cortisone interconversion were barely detectable in these tissues. Therefore, biological roles for the $11 \beta \mathrm{HSD}$ enzymes seem unlikely in these regions of the porcine reproductive tract.

In our initial enzyme activity studies, the boar bulbourethral glands displayed predominant $\mathrm{NADP}^{+}$dependent $11 \beta \mathrm{DH}$ activities, whereas the penile urethra exhibited predominantly $\mathrm{NAD}^{+}$-dependent cortisol oxidation. In both of these tissues, the predominant direction of $11 \beta \mathrm{HSD}$ enzyme activity in vitro was to inactivate cortisol. The bulbourethral gland secretes

Table 2 Kinetic parameters for $\mathrm{NADP}(\mathrm{H})$-dependent cortisol-cortisone metabolism.

\begin{tabular}{|c|c|c|c|c|c|}
\hline & \multicolumn{2}{|c|}{ NADPH-dependent $11 \mathrm{KSR}$ activity } & \multicolumn{2}{|c|}{$\mathrm{NADP}^{+}$-dependent $11 \beta \mathrm{DH}$ activity } & \multirow[b]{2}{*}{ NADP $^{+}:$NADPH } \\
\hline & $K_{\mathrm{m}}(\mathrm{nmol} / \mathrm{l})$ & $V_{\max }(\mathrm{pmol}$ cortisol/h) & $K_{\mathrm{m}}(\mathrm{nmol} / \mathrm{l})$ & $V_{\max }(\mathrm{pmol}$ cortisol/h) & \\
\hline Testis & $280 \pm 70$ & $2.7 \pm 0.9$ & $254 \pm 56$ & $19.0 \pm 6.0$ & $9.9 \pm 4.3$ \\
\hline Caput epididymidis & $132 \pm 42$ & $1.7 \pm 0.4$ & $237 \pm 46$ & $12.2 \pm 1.7$ & $7.4 \pm 0.8$ \\
\hline Bulbourethral gland & $219 \pm 155$ & $2.1 \pm 1.6$ & $443 \pm 158$ & $18.1 \pm 6.2$ & $28.5 \pm 14.2$ \\
\hline
\end{tabular}

$11 \mathrm{KSR}$ activities were measured in the presence of $0.4 \mathrm{mmol} / \mathrm{I}$ NAPH plus $10 \mathrm{mmol} / \mathrm{l}$ G6P over $2 \mathrm{~h} ; 11 \beta \mathrm{DH}$ activities were measured in the presence of $0.4 \mathrm{mmol} / \mathrm{I} \mathrm{NADP}{ }^{+}$over $2 \mathrm{~h}$. Data are presented as the mean \pm s.E.M. estimates of $K_{\mathrm{m}} / V_{\max }$ with each cofactor in each tissue, where each value was estimated in triplicate for each of three independent boars. The mean \pm s.E.M. ratio of NADP ${ }^{+}$-dependent $11 \beta \mathrm{DH}$ activities to NADPHdependent $11 \mathrm{KSR}$ activities (NADP ${ }^{+}: \mathrm{NADPH}$ ) were estimated using the matched $V_{\max }$ estimates for these three boars. Within each column, estimates did not differ significantly between tissues (one-way ANOVA, $P>0.05$ ). 
Table 3 Kinetic parameters for $\mathrm{NAD}^{+}$-dependent cortisol oxidation.

\begin{tabular}{llc}
\hline & \multicolumn{2}{c}{ NAD $^{+}$-dependent 11 } \\
\cline { 2 - 3 } & $K_{\mathrm{m}}(\mathrm{nmol} / \mathrm{l})$ & $V_{\max }(\mathrm{pmol}$ activity \\
\hline Testis & $154 \pm 69$ & $10.0 \pm 2.7$ \\
Caput epididymides & $226 \pm 125$ & $11.2 \pm 5.8$ \\
Bulbourethral glands & $208 \pm 35$ & $10.2 \pm 1.5$ \\
\hline
\end{tabular}

Net11 $\beta \mathrm{DH}$ activities were measured in the presence of $0.4 \mathrm{mmol} / \mathrm{I}$ $\mathrm{NAD}^{+}$over $2 \mathrm{~h}$. Data are presented as the mean \pm s.E.M. estimates of $K_{\mathrm{m}} / V_{\max }$ with $\mathrm{NAD}^{+}$in each tissue, where each value was estimated in triplicate for each of the three independent boars. Within each column, estimates did not differ significantly between tissues (one-way ANOVA, $P>0.05$ ).

glycoproteins and antigens previously thought to help in the immune defence of the reproductive tract (Chughtai et al. 2005). Our current data raise the possibility that local expression and activity of $11 \beta \mathrm{HSD} 1$ might also contribute to the protective role of the bulbourethral gland, protecting spermatozoa by decreasing cortisol concentrations in semen prior to ejaculation.

Turning finally to enzyme activities in the positive control tissues for our enzyme activity assays, previous studies have established that in the rat liver, 11ßHSD1 acts predominantly as an $11 \mathrm{KSR}$ enzyme (Krozowski \& Funder 1983, Seckl \& Walker 2001). However, in the current study, both the $\mathrm{NADP}^{+}$- and $\mathrm{NAD}^{+}$-dependent dehydrogenase activities in boar liver homogenates appeared to be higher than the NADPH-dependent oxo-reductase activity, despite the addition of an excess of exogenous pyridine dinucleotide co-substrates. In the rat kidney, $\mathrm{NAD}^{+}$-dependent $11 \beta \mathrm{DH}$ activities have been reported with the expression of $11 \beta \mathrm{HSD} 2 \mathrm{mRNA}$ and protein localised to the distal nephron and renal collecting ducts (Edwards et al. 1988, Mercer \& Krozowski 1992, Walker et al. 1992, Whorwood et al. 1995). We now report that, both $11 \beta \mathrm{HSD} 1$ and $11 \beta \mathrm{HSD} 2 \mathrm{mRNA}$ and protein were co-expressed in pig kidneys, which not only exhibited relatively high rates of $\mathrm{NAD}^{+}$-dependent cortisol oxidation, but also displayed some $\mathrm{NADP}^{+}$-dependent $11 \beta \mathrm{DH}$ activity.

In conclusion, we have demonstrated that $11 \beta \mathrm{HSD} 1$ and $11 \beta \mathrm{HSD} 2$ protein and $\mathrm{mRNA}$ are co-expressed in the boar testis and throughout the male reproductive tract. Homogenates of boar testis, caput epididymidis and bulbourethral gland each show predominant $11 \beta \mathrm{DH}$ activities in vitro, with comparable $V_{\max }$ estimates using either $\mathrm{NADP}^{+}$or $\mathrm{NAD}^{+}$as the reaction co-substrates. Assuming that our in vitro measurements of enzyme activities reflect the balance of GC metabolism in vivo, we would speculate that the $11 \beta \mathrm{HSD}$ enzymes could act in the testis and reproductive tract of the boar to limit the local actions of cortisol. Differences between the kinetics of cortisol oxidation in these boar tissues as compared with the cloned rat and human $11 \beta \mathrm{HSD}$ enzymes suggest that either the porcine $11 \beta \mathrm{HSD}$ enzymes have speciesspecific kinetic properties or the affinities of the boar enzymes are locally modulated within the boar testis and male reproductive tract tissues.

\section{Acknowledgements}

We wish to acknowledge A\&G Barber slaughterhouse, Chelmsford, Essex for supplying all boar testis and reproductive tract tissues. We would also like to thank Prof. P Stewart

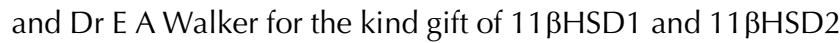
primary antibodies, Prof. M Binns and Mrs $\mathrm{K}$ Dominy for sequencing PCR products and Ms Helen Smith for assistance with confocal microscopy. We would also like to acknowledge Dr K C Jonas and Miss N Sunak for technical help with aspects of this project. This work was funded by a RVC PhD studentship, awarded to LMT and AEM (to support VS), and by a RVC start-up grant to RCF. The authors declare that there is no conflict of interest that would prejudice the impartiality of this scientific work.

\section{References}

Agarwal A, Mune T, Monder C \& White P $1994 \mathrm{NAD}^{+}$-dependent isoform of $11 \beta$-hydroxysteroid dehydrogenase. Cloning and characterisation of cDNA from sheep kidney. Journal of Biological Chemistry $26925959-25962$.

Albiston AL, Obeyesekere VR, Smith RE \& Krozowski ZS 1994 Cloning and tissue distribution of the human 1/ $\beta$-hydroxysteroid dehydrogenase type 2 enzyme. Molecular and Cellular Endocrinology 105 R11-R17.

Atanasov AG, Nashev LG, Schweizer RA, Frick C \& Odermatt A 2004 Hexose-6-phosphate dehydrogenase determines the reaction direction of $11 \beta$-hydroxysteroid dehydrogenase type 1 as an oxoreductase. FEBS Letters 571 129-133.

Bambino T \& Hsueh A 1981 Direct inhibitory effect of glucocorticoids upon testicular luteinising hormone receptor and steroidogenesis in vivo and in vitro. Endocrinology 108 2142-2148.

Banhegyi G, Benedetti A, Fulceri R \& Senesi S 2004 Cooperativity between $11 \beta$-hydroxysteroid dehydrogenase type 1 and hexose-6phosphate dehydrogenase in the lumen of the endoplasmic reticulum. Journal of Biological Chemistry 279 27017-27021.

Bujalska IJ, Draper N, Michailidou Z, Tomlinson JW, White PC, Chapman KE, Walker EA \& Stewart PM 2005 Hexose-6-phosphate dehydrogenase confers oxo-reductase activity upon $11 \beta$-hydroxysteroid dehydrogenase type 1. Journal of Molecular Endocrinology 34 675-684.

Bush IE, Hunter SA \& Meigs RA 1968 Metabolism of 11-oxygenated steroids, Metabolism in vitro by preparations of liver. Biochemical Journal 107 239-258.

Chughtai B, Sawas A, O'Malley RL, Naik RR, Ali Khan S \& Pentyala S 2005 A neglected gland: a review of Cowper's gland. International Journal of Andrology 28 74-77.

Claus R, Wagner A \& Lambert T 2005 Characterisation of $11 \beta$ hydroxysteroid dehydrogenase activity in testicular tissue of control and GnRH-immunized boars as a possible regulator of spermatogenesis. Experimental and Clinical Endocrinology Diabetes 113 262-267.

Draper N, Walker EA, Bujalska IJ, Tomlinson JW, Chalder SM, Arlt W, Lavery GG, Bedendo O, Ray DW, Laing I et al. 2003 Mutations in the genes encoding $11 \beta$-hydroxysteroid dehydrogenase type 1 and hexose-6-phosphate dehydrogenase interact to cause cortisone reductase deficiency. Nature Genetics 34 434-439. 
Edwards CR, Stewart PM, Burt D, Brett L, McIntyre MA, Sutanto WS, de Kloet ER \& Monder C 1988 Localisation of 11 $\beta$-hydroxysteroid dehydrogenase - tissue specific protector of the mineralocorticoid receptor. Lancet 2 986-989.

Ferrari P, Smith RE, Funder JW \& Krozowski ZS 1996 Substrate and inhibitor specificity of the cloned human $11 \beta$-hydroxysteroid dehydrogenase type 2 isoform. American Journal of Physiology 270 E900-E904.

Gao H-B, Ge R-S, Lakshmi V, Marandici A \& Hardy MP 1997 Hormonal regulation of oxidative and reductive activities of $11 \beta$ hydroxysteroid dehydrogenase in rat Leydig cells. Endocrinology 138 156-161.

Ge RS \& Hardy MP 2000 Initial predominance of the oxidative activity of type I 11ß-hydroxysteroid dehydrogenase in primary rat Leydig cells and transfected cell lines. Journal of Andrology 21 303-310.

Ge R-S, Gao H-B, Nacharaju VL, Gunsalus GL \& Hardy MP 1997 Identification of a kinetically distinct activity of $11 \beta$-hydroxysteroid dehydrogenase in rat Leydig cells. Endocrinology 138 2435-2442.

Ge RS, Dong Q, Niu EM, Sottas CM, Hardy DO, Catterall JF, Latif SA, Morris DJ \& Hardy MP 2005 11ß-hydroxysteroid dehydrogenase 2 in rat Leydig cells: its role in blunting glucocorticoid action at physiological levels of substrate. Endocrinology 146 2657-2664.

Gomez-Sanchez EP, Cox D, Foecking M, Ganjam V \& GomezSanchez CE 1996 11ß-hydroxysteroid dehydrogenases of the choriocarcinoma cell line JEG-3 and their inhibition by glycyrrhetinic acid and other natural substances. Steroids 61 110-115.

Gomez-Sanchez EP, Ganjam V, Chen YJ, Cox DL, Zhou MY, Thanigaraj S \& Gomez-Sanchez CE 1997 The sheep kidney contains a novel unidirectional, high affinity $\mathrm{NADP}^{+}$-dependent $11 \beta$ hydroxysteroid dehydrogenase (11ßHSD3). Steroids 6 444-450.

Krozowski ZS \& Funder JW 1983 Renal mineralocorticoid receptors and hippocampal corticosterone-binding species have identical intrinsic steroid specificity. PNAS $\mathbf{8 0}$ 6056-6060.

Lange F, Aigner B, Muller M \& Claus R 2003 Porcine $11 \beta$ hydroxysteroid dehydrogenase type 2 isoform: complete coding sequence and polymorphisms. Animal Biotechnology 14 13-17.

Latif SA, Pardo HA, Hardy MP \& Morris DJ 2005 Endogenous selective inhibitors of $11 \beta$-hydroxysteroid dehydrogenase isoforms 1 and 2 of adrenal origin. Molecular and Cellular Endocrinology 243 43-50.

McCormick KL, Wang X \& Mick GJ 2006 Evidence that the $11 \beta$ hydroxysteroid dehydrogenase $(11 \beta \mathrm{HSD} 1)$ is regulated by pentose pathway flux, Studies in rat adipocytes and microsomes. Journal of Biological Chemistry 281 341-347.

Mercer W \& Krozowski Z 1992 Localisation of an $11 \beta$-hydroxysteroid dehydrogenase activity to the distal nephron. Evidence for the existence of two species of dehydrogenase in the rat kidney. Endocrinology 130 540-543.

Michael AE, Evagelatou M, Norgate DP, Clarke RJ, Antoniw JW, Stedman BA, Brennan A, Welsby R, Bujalska I, Stewart PM et al. 1997 Isoforms of $11 \beta$-hydroxysteroid dehydrogenase in human granulosa-lutein cells. Molecular and Cellular Endocrinology 132 43-52.

Michael AE, Thurston LM \& Rae MT 2003 Glucocorticoid metabolism and reproduction: a tale of two enzymes. Reproduction $\mathbf{1 2 6}$ 425-441.

Monder C, Hardy MP, Blanchard RJ \& Blanchard DC 1994a Comparative aspects of $11 \beta$-hydroxysteroid dehydrogenase.
Testicular $11 \beta$-hydroxysteroid dehydrogenase: development of a model for the mediation of Leydig cell function by corticosteroids. Steroids 59 69-73.

Monder C, Miroff Y, Marandici A \& Hardy M 1994b 11ßHydroxysteroid dehydrogenase alleviates glucocorticoid-mediated inhibition of steroidogenesis in rat Leydig cells. Endocrinology 134 1199-1204.

Morita H, Zhou M, Foecking MF, Gomez-Sanchez EP, Cozza EN \& Gomez-Sanchez CE 1996 11 $\beta$-Hydroxysteroid dehydrogenase type 2 complementary deoxyribonucleic acid stably transfected into Chinese hamster ovary cells: specific inhibition by $11 \alpha$-hydroxyprogesterone. Endocrinology 137 2308-2314.

Pearce PT, Lipkevicius OR \& Funder JW 1986 High affinity (type 1) aldosterone-binding sites in rat epididymis. Endocrinology $\mathbf{1 1 8}$ 2072-2075.

Phillips ML \& Schultz BD 2002 Steroids modulate transepithelial resistance and $\mathrm{Na}^{+}$absorption across cultured porcine vas deferens epithelia. Biology of Reproduction 66 1016-1023.

Phillips D, Lakshmi V \& Monder C 1989 Corticosteroid 11 $\beta$ dehydrogenase in rat testis. Endocrinology 125 209-216.

Pushkin A, Clark I, Kwon TH, Nielsen S \& Kurtz I 2000 Immunolocalisation of $\mathrm{NBC3}$ and $\mathrm{NHE3}$ in the rat epididymis: colocalisation of $\mathrm{NBC} 3$ and the vacuolar $\mathrm{H}^{+}$-ATPase. Journal of Andrology 21 708-720.

Seckl JR \& Walker BR 2001 11 $\beta$-hydroxysteroid dehydrogenase type 1 - A tissue-specific amplifier of glucocorticoid action. Endocrinology 142 1371-1376.

Souness GW, Latif SA, Laurenzo JL \& Morris DJ $199511 \alpha$ - and $11 \beta$ hydroxyprogesterone, potent inhibitors of $11 \beta$-hydroxysteroid dehydrogenase (isoforms 1 and 2), confer marked mineralocorticoid activity on corticosterone in the ADX rat. Endocrinology 136 1809-1812.

Sunak N, Green DF, Abeydeera LR, Thurston LM \& Michael AE 2007 Implication of cortisol and $11 \beta$-hydroxysteroid dehydrogenase $(11 \beta \mathrm{HSD})$ enzymes in the development of porcine (Sus scrofa domestica) ovarian follicles and cysts. Reproduction 133 1149-1158.

Thurston LM, Abayasekara DRE \& Michael AE 2007 11 $\beta$-Hydroxysteroid dehydrogenase (11 $\beta$ HSD) expression and activities in bovine granulosa cells and corpora lutea implicate corticosteroids in bovine ovarian physiology. Journal of Endocrinology 193 299-310.

Waddell BJ, Hisheh S, Krozowski ZS \& Burton PJ 2003 Localisation of $11 \beta$-hydroxysteroid dehydrogenase types 1 and 2 in the male reproductive tract. Endocrinology 144 3101-3106.

Walker BR, Campbell JC, Williams BC \& Edwards CR 1992 Tissuespecific distribution of the $\mathrm{NAD}^{+}$-dependent isoform of $11 \beta$ hydroxysteroid dehydrogenase. Endocrinology 131 970-972.

Whorwood CB, Mason JI, Ricketts ML, Howie AJ \& Stewart PM 1995 Detection of human $11 \beta$-hydroxysteroid dehydrogenase isoforms using reverse-transcriptase-polymerase chain reaction and localisation of the type 2 isoform to renal collecting ducts. Molecular and Cellular Endocrinology 110 R7-12.

Received 16 March 2007

First decision 20 April 2007

Accepted 5 June 2007 